\title{
Investment, Efficiency, and Credit Rationing: \\ Evidence from Hungarian Panel Data
}

\author{
By: Mathilde Maurel
}

William Davidson Working Paper Number 403

November 2001 


\title{
InVESTMENT, EFFICIENCY, AND CREDit RATIONING: EVIDENCE FROM HUNGARIAN PANel Data
}

\author{
MATHILDE MAUREL ${ }^{\text {L }}$
}

\begin{abstract}
Relying upon a rich and unique panel of Hungarian firms over 7 years, from 1992 up to 1998, this paper estimates simultaneously TFP, Total Factor Productivity, identified as efficiency, and the parameters of a model where investment depends upon internal funds, wages, and sales, as in Prasnikar J. and Svejnar J. (2000). It shows that while real investment is higher in foreign firms, the improvement in efficiency due to investment is significantly higher in Hungarian domestic firms. We test the possibility that this higher than average foreign investment may exacerbate other firms credit constraints by crowding them out of domestic capital markets. Of course one must control for that foreign firms may simply be more profitable and have access to more collateral, hence be a better investment for lending institutions. All firms (foreign, private and domestically owned, and State-owned) are credit rationed, including foreign firms. State-owned firms do not have an investment behaviour compatible with profit maximisation, a result which emphasises the soft budget constraint persistence (but not through the providing with soft credit). For these firms, wages increase together with investment.
\end{abstract}

JEL Classification : E22, G32, P21, D21, D92

Key Words: Investment, Credit rationing, Soft budget constraint, Ownership, Transition to a market economy, Hungary.

\footnotetext{
${ }^{1}$ This paper benefited from a Phare-Ace grant. I would like to thank Jérôme Sgard for useful comments. The paper also benefited from presentation at the June 2001 workshop in Budapest.

2 ROSES (CNRS), Centre François Simiand, and CEPR, Maison des Sciences Economiques, 106-112 Bd de l’Hôpital, 75013 Paris, France. Tel : 331440783 44. Email: Maurelm@ univ-paris1.fr
} 


\section{Non-technical summary}

1. Contrary to other transition countries, like Bulgaria, Romania (see Budina and alii, 2000), or even the Czech Republic (see Estrin and alii, 2001), transition seems to be over in Hungary in the sense that the soft budget constraint has been significantly reduced. In particular, the banking system does not more provide (State-owned) loss makers with cheap credit, allowing them to survive despite their losses.

2. The decade has been characterised by a significant decrease in investment, which could have been justified in the first years for restructuring purposes, but now might jeopardise further restructuring. In the paper we test the credit rationing assumption, which is validated for all categories of ownership.

3. Domestic private firms are no less efficient than foreign firms, but, although the elasticity of efficiency with respect to investment is lower for the latter, they are exposed to a much larger credit rationing. This credit rationing is partially the consequence of their crowding out by foreign firms. Anyway, one policy implication is that improving the way credit is distributed towards domestic firms would probably enhance overall efficiency.

4. For what regards the EU enlargement towards CECs (Central European Countries), the Hungarian case might suggest that one way of making domestic firms more efficient (and more able to compete in the international market) would be to improve their access to credit.

5. Finally one specific feature of the Hungarian transition is the economic weight of foreign firms: whatever the indicator (total assets, labour, investment), foreign firms seem to be at the core of the economic recovery and growth in Hungary. One implication for other transition countries would be that being more efficient than domestic firms, these firms are in a position of easing the economic restructuring of a country deprived for a long period of time from any access to international competition and international markets. The diffusion of expertise, the existence of technological spillovers, the example of the proper corporate governance scheme, constitute positive externalities. Nevertheless, one should be aware that discouraged (domestic) firms might well exit in the long run, particularly if they face unequal conditions on the financial market. 


\section{$\underline{\text { Introduction }}$}

For explaining the firms improvement in efficiency during the transition process, one usually stresses the role of macroeconomic adjustment which induces the deep and painful microeconomic restructuring at the core of the transition success. In the earlier years of transition, the key for recovering is both addressing the problem of capacity under-utilization and hardening the budget constraint, while because of hazard moral and adverse selection banks are providing loss makers with cheap credit Then investment becomes an important factor of economic growth, particularly in the new private sector.

In market economies one important impediment to an optimal and unbiased level of investment is that certain firms ${ }^{2}$ might face a credit rationing implying that the level of investment is correlated with internal funds, while for other (unconstrained) firms this correlation does not exist. In transition economies, the argument has to be balanced against that telling that the distortion may work in the opposite way, and that unconstrained firms may be firms already indebted, benefiting from repeated bailouts, and nevertheless provided with external finance despite their losses. The soft budget constraint can therefore be revealed through the distorted access to financial market. Complementary evidence is the loosening of central controls in the absence of competitive pressures and the control by workers-insiders which can translate into excessive wage increases and have an impact on investment through the trade-off between investment and wage increases. For assessing the extent to which the soft budget constraint still works in Hungary, we estimate an Euler equation where investment is determined by three factors, the arbitrage between investment and wage increases, the output demand which in the neoclassical and accelerator models of investment enhances investment, and the availability of internal funds.

We estimate in section 1 two measures of efficiency, which are Total Factor Productivity computed from a Cobb-Douglas technology excluding and including property dummies. The relative share of investment in foreign firms is significantly higher than that of other firms in the sample, but the elasticity of efficiency with respect to investment is lower than that of private and domestically owned enterprises. Under the assumption that the technology is concave, this results suggests that Hungarian firms are on a point where the marginal productivity of capital is higher than where foreign firms stand. If marginal productivity of capital is higher in Hungarian firms, the question of whether domestic firms, either privately

\footnotetext{
${ }^{1}$ Subsequently investment behaviors might become more important, and indeed it is identified as an indicator of deep microeconomic restructuring (Grosfeld and Roland (1997)).

${ }^{2}$ Small firms, highly indebted, domestic versus foreign in developing countries: for a listing of all $a$
} 
or State-owned, may be crowed out by foreign firms has to be asked (in section 3). Based upon the Euler equation mentioned above, section 2 shows that a credit market imperfection holds for all categories of firms, including State owned firms, contrary to the assumption of the failure of the banking system to enforce an efficient allocation of funds by distorting the access to external funds for the less efficient firms in the sample ${ }^{\text {B }}$.

\section{Section 1: Efficiency by category of firms, Investment}

The dataset used in this paper is extremely rich and representative; it covers all registered enterprises with at least 20 employees on average, between 1993 and 1998. It contains balance sheets, income statements, structure of ownerships, and number of employees. The individual and time structure allows to perform the usual panel analysis. All figures are nominal and deflated using a two-digit sector price index, which was obtained from the Central Statistical Office.

The values of equity owned by respectively the State, Hungarians, and Foreigners are reported and allow to control for different categories of ownership: foreign versus domestic private. The dualistic approach distinguishing foreign from domestic firms is particularly required for Hungary, given the strategy of radical openness towards FDI and access to ownership by foreigners implemented by the Hungarian authorities ${ }^{1}$.

Table 1 in the annex reports the means, standard deviations, and numbers of observations for all variables used throughout the paper. For some size variables, like total assets and the number of employees, State-owned firms turn out to be much bigger, at least at the beginning of the period. However one can observe a significant decrease in these variables over the decade (for the average number of employees, by a factor of no less than $30 \%$ ). By contrast the difference, in particular between State-owned and foreign enterprises, is no more significant when one looks at net sales revenues: 1083468 thousands forints for foreign firms over the period, but only 1031624 thousands forints for State-owned firms.

By looking at some selected indicators of performance, the picture is slightly different. Stateowned firms are no more first in the ranking: (annual) net sales revenues by employee reach only 2253 thousands forints, while for foreign firms the figure is twice as big (5211

priori groupings, see Hubbard (1998).

3 The situation in CEECs seems to be quite contrasted : Estrin and al. (1993) show that banks with large amount of bad loans seem to monitor new credits in a satisfactory way. This is not the case in Bulgaria, see Budina Nina and al. (2001).

${ }^{4}$ In Laslo Halpern and Gabor Korosi (2000), different measures of (in-)efficiency indicate a strong differentiation between foreign and domestic enterprises. State-owned enterprises are not found to be much less efficient than domestic private owned firms, which implies that the unequal efficiency can only partially be explained in the usual corporate governance framework (quality of management). 
thousands forints). For what regards payment to employees, state-owned firms pay an average amount of 465, while foreign firms pay a slightly higher amount, 594. The same picture, but much more pronounced, can be drawn from the trading profit by employee variable, whom means are respectively 143 and 594 .

Hungarian firms investment, roughly computed as the increase (decrease) in real terms in total assets minus depreciation charges, is very low over the whole period (and negative: 226379 thousands forints)), except foreign firms investment, which is positive and averaged over the period represents 71132 thousands forints. Investment breaks up in the first years of the transition process. But from 93-94 onwards it recovers firmly: in 1998 it is again positive and represents respectively 97444 thousands forints (State-owned firms), - 4143 thousands forints (private domestic firms), and 120596 thousands forints (foreign firms).

These preliminary statistics suggests several facts that are well-known in the transition countries: private domestic firms, either privatised or de novo firms, are generally smaller than State-owned firms, in terms of employment (particularly) or total assets. Ownership structure matter, the performance of private entities being better than that of State-owned. And finally while investment drops hugely in the first years, one can observe a significant recovery in the following years.

One specific feature in Hungary, emphasised in Table 1, is the dualistic structure of the economy: the presence and economic weight of foreign firms is striking. The latter invest more, and according to the efficiency indicators provided in table 1 (trading profit by employee, wage payment, net sale revenue by employee), they are apparently more efficient than their Hungarian counterpart.

\section{1: Efficiency}

In that section we estimate in a more traditional way firm level efficiencies. Total factor productivity (TFP hereafter) is derived from the following two basic equations:

$\log (\mathrm{Y}(\mathrm{i}, \mathrm{t}))=$ constant $+\mathrm{c}$ year $+\mathrm{a} \log (\mathrm{L}(\mathrm{i}, \mathrm{t}))+\mathrm{b} \log (\mathrm{K}(\mathrm{i}, \mathrm{t}))+\mathrm{v}(\mathrm{i}, \mathrm{t})+\mathrm{u}(\mathrm{i})$

Or equivalently :

$y(i, t)=$ constant $+c$ year $+a 1(i, t)+b k(i, t)+v(i, t)+u(i)$

$\log (\mathrm{Y}(\mathrm{i}, \mathrm{t}))=$ constant $+\mathrm{c}$ year $+\mathrm{a} \log (\mathrm{L}(\mathrm{i}, \mathrm{t}))+\mathrm{b} \log (\mathrm{K}(\mathrm{i}, \mathrm{t}))+$ ej $\operatorname{propj}+\mathrm{v}(\mathrm{i}, \mathrm{t})+\mathrm{u}(\mathrm{i}) \quad(\mathrm{Eq} .2)$

Or equivalently :

$\mathrm{y}(\mathrm{i}, \mathrm{t})=$ constant $+\mathrm{c}$ year $+\mathrm{a} \mathrm{l}(\mathrm{i}, \mathrm{t})+\mathrm{b} \mathrm{k}(\mathrm{i}, \mathrm{t})+\mathrm{ej} \operatorname{propj}+\mathrm{v}(\mathrm{i}, \mathrm{t})+\mathrm{u}(\mathrm{i})$

${ }^{5}$ Indeed $\left.30 \%=(382-250) / 382\right)$, see table 1. 
Where :

$\mathrm{L}(\mathrm{i}, \mathrm{t})$ is the average number of employees at date $\mathrm{t}$;

$\mathrm{K}(\mathrm{i}, \mathrm{t})$ is the total assets at date $\mathrm{t}$ (in thousands of forints);

$\mathrm{Y}(\mathrm{i}, \mathrm{t})$ are net sales revenues at date $\mathrm{t}$ (in thousands of forints);

Propj indicates the share in percent of equities owned by the State, by Hungarian firms, and by Foreigners.

$\mathrm{U}(\mathrm{i})$ is the fixed effect picking up firms heterogeneity, the residual $v(\mathrm{i}, \mathrm{t})$ has the usual properties (that is normally distributed with zero mean and constant standard error).

We define TFP in two different manners:

TFP including the effect of corporate governance, which is assumed to depend upon the ownership structure of the firms (more private firms are expected to be more efficient). TFP is computed as the residual from equations 1 and $1 \mathrm{~b}$ where property variables are not included as explanatory variables ${ }^{\text {t }}$.

TFP net of the quality of the corporate governance scheme, computed as the residual $u(i)$ in equation 2 or $2 b$.

Results are reported in tables 1 and 2. The propj dummy coefficients imply that TFP decreases when the share of equities owned by the State increases, and conversely increases, by the same magnitude, when the share of either foreign or domestic private increases. As a consequence TFP including the effect of ownership structure is lower in the sub-sample of State-owned firms. Although the discrepancy between the two measures of efficiency (including and excluding the effect of corporate governance) in, say, State-owned and private domestic firms, is significantly reduced 7 efficiency is still significantly lower in State-owned firms even when we take away the ownership structure component of efficiency (see table 1). One possible interpretation is that the distribution of efficiency across firms cannot be reduced to different endowments in corporate governance and management skills, as proxied by the share of equities owned by private entities. Some authors argue indeed that ownership and competitive pressure are complementary, which implies that a change in ownership, if not reinforced by the proper competition institutions, does not necessarily influence firm

\footnotetext{
6 A similar interpretation for the fixed effect can be found in Cull and Xu (2000): « the interpretation of the coefficients for the financial variables changes with the inclusion of firm dummies. The coefficients reflect effects net of those due to bank screening based on firm heterogeneity, effects for instance due to monitoring. » (page 16).

${ }^{7}$ In other words, the difference between -0.36 and 0.12 in table 1 is higher than that between -0.13 and 0.012 . This is because the former measure of efficiency includes corporate governance, proxied here by the propj variables, which is higher in private firms and lower in State-owned firms.
} 
performance ${ }^{\mathrm{B}}$. This would explain why privatisation succeeded in some countries, mainly in Central Europe, and failed in others, like CIS, Romania, Bulgaria. In the case of Hungary, we keep in mind (1) that State-owned firms are definitely less efficient than other firms in the sample, even by controlling for the ownership structure ${ }^{\text {9 }}$ (2) that domestic private firms turn out (somehow surprisingly ?) to be as efficient as foreign firms. Our objective is now to explore the interaction between TFP and investment, then to answer the question whether foreign firms might have crowed out domestic firms.

Table 2: equation 2 estimates

\begin{tabular}{|c|c|c|}
\hline & Coefficient & Z statistics \\
\hline $\mathrm{L}$ & 0.65 & 112.80 \\
\hline $\mathrm{K}$ & 0.46 & 98.05 \\
\hline Equities owned by the State & -0.200 & -3.078 \\
\hline $\begin{array}{c}\text { Equities owned by domestic } \\
\text { private firms }\end{array}$ & 0.125 & 1.929 \\
\hline $\begin{array}{c}\text { Equities owned by foreign } \\
\text { firms }\end{array}$ & 0.158 & 2.391 \\
\hline $\mathrm{R} 2$ within & 0.5618 & \\
\hline R2 between & 0.7607 & \\
\hline R2 total & 0.7509 & \\
\hline Number of observations & 30719 & \\
\hline Number of groups & 8107 & \\
\hline
\end{tabular}

Returns to scale in table 2 are increasing $\frac{10}{8}$.

\section{2: Investment}

If investment were accumulated by firms recording the lower efficiency score, it would imply the possibility that the allocation of credit is biased towards less profitable firms, and that a process of credit rationing, where bad firms would no more be provided with cheap credit, would contribute to hardening the budget constraint. In Hungary, such a policy implication is not likely to be adapted to the economic situationt average investment, as seen in the above section, is negative - which could end up with a credit crunch (as emphasised in Calvo and Coricelli (1994)) - hence a more relevant issue is that of a possible market imperfection implying that firms, whatever their efficiency, are credit rationed. The answer has to be balanced: investment is significantly higher in foreign firms, which are also more efficient than State-owned firms in the sample, but private domestic firms, although as efficient as foreign firms, do not invest as much.

\footnotetext{
${ }^{8}$ See Estrin and alii (2001), Grosfeld and Tressel (2001).

${ }^{9}$ Even if controlling reduces the gap in efficiency.

${ }^{10}$ The same result of increasing returns was found in Laslo Halpern and Gabor Korosi (2000).

${ }^{11}$ While according to Budina Nina and al. (2001) credit rationing in Bulgaria is harder amongst private
} 
Another question regards the nature of the externality produced by foreign firms on the domestic market. For Estrin and alii (2001): "If competition between similarly productive and technologically advanced firms might eventually lead to restructuring and to improved performance, the presence of much better firms in the same market may discourage enterprise restructuring". One explanation is that discouraged enterprises are exiting in the long run. Another explanation, which we explore here, is that better (foreign) firms might force domestic firms to exit simply by crowing them out, via financial market (they have an easier access, whatever domestic or international, to capital) and via product market (banks prefer to provide foreign firms with the available credit).

In table 3, the explained variable is the yearly share of funds, in per cent of total positive funds, invested by State-owned firms, Hungarian private firms, and foreign firms that for most observations, real investment is null or even negative, an Heckman procedure is required ${ }^{13}$. The probability for State-owned firms of registering positive values of investment is significantly lower; furthermore, the probability for foreign firms of investing is 10 points higher than for Hungarian private firms. Given those differentiated probabilities, Hungarian private firms invest more than State-owned firms. The coefficient is positive and set equal to 0.21 , while not significantly different from zero in the case of State-owned firms. Furthermore, foreign firms are not only likely to invest more, but their investment is also significantly dramatically higher (with a coefficient reaching 0.63 ). These results corroborate the simple means reported in table 1.

In table 4 we focus on the correlation between investment and our two measures of efficiency, gross and net of property structure. Proceeding that way we are really able to capture the link between improvement in the ratio of output on inputs (allowed by any technical progress or whatever), that is between efficiency, pure of the corporate governance's quality (which does not depend upon the amount of investment), and investment itself.

\footnotetext{
firms, and softer in firms provided with cheap credit (corresponding to bad loans).

${ }^{12}$ For clarity purpose State-owned firms, co-operatives, and non profit institutions are merged together. Notice that co-operatives and non profit institutions represent a small share of the total.

${ }^{13}$ where both the probability for real investment to be positive, and then the structural equation, are estimated.
} 
Table 3: investment shares estimates

\begin{tabular}{|l|l|l|}
\hline Structural Equation & Coefficients & Z statistics \\
\hline $\begin{array}{l}\text { Dummy set equal to one when } \\
\text { the majority of equities is owned } \\
\text { by the State }\end{array}$ & 0.005 & 3.33 \\
\hline $\begin{array}{l}\text { Dummy set equal to one when } \\
\text { the majority of equities is owned } \\
\text { by private domestic firms }\end{array}$ & 0.212 & 144.87 \\
\hline $\begin{array}{l}\text { Dummy set equal to one when } \\
\text { the majority of equities is owned } \\
\text { by foreign firms }\end{array}$ & 0.631 & 404.34 \\
\hline Constant & 0.030 & 21.61 \\
\hline & & \\
\hline Selection Equation & -0.245 & -5.72 \\
\hline $\begin{array}{l}\text { Dummy set equal to one when } \\
\text { the majority of equities is owned } \\
\text { by the State }\end{array}$ & Coefficients & \\
\hline $\begin{array}{l}\text { Dummy set equal to one when } \\
\text { the majority of equities is owned } \\
\text { by private domestic firms }\end{array}$ & 0.205 & 5.18 \\
\hline $\begin{array}{l}\text { Dummy set equal to one when } \\
\text { the majority of equities is owned } \\
\text { by foreign firms }\end{array}$ & 0.30 & \\
\hline Constant & 0.798 & 20.95 \\
\hline Number of observations & & \\
\hline $\begin{array}{l}\text { Number of censored } \\
\text { observations }\end{array}$ & & \\
\hline Wald Statistics Chi2(3) & & \\
\hline Log Likelihood & & \\
\hline
\end{tabular}

Table 4 confirms the statistics in table 1, reflecting that efficiency (whatever gross or net) reaches the same value in Hungarian private firms and in foreign firms, but is significantly lower in State-owned firms. The average elasticity of efficiency with respect to investment, estimated at 0.087 , is significant and positive.

By assuming now that the elasticity of efficiency with respect to investment might differ across firms, we find indeed that the degree of significance is dramatically weakened in the sub-sample of State-owned firms; nevertheless it remains significant (but only at 10\%) if we consider efficiency net of the ownership structure. One possible objection is that State-owned firms investment is negative all during the period; but dis-investment could in principle enhance efficiency and reflect an adjustment process where the general over capacities of the firms would be reduced to a more efficient level. Given the absence of any strong correlation between the decline in assets and efficiency, this assumption is not validated.

Now the efficiency of investment in improving TFP is much (twice) higher in the sub-sample of Hungarian private firms that in the sub-sample of foreign firms. The marginal productivity of an incremental unit of capital is therefore higher in the former group, where both the stock 
and flow of productive capital are lower. This is another important result, which stress the importance of the crowding out hypothesis to be tested.

Table 4 : efficiency elasticity with respect to investment

\begin{tabular}{|c|c|c|c|c|}
\hline \multicolumn{5}{|c|}{ Net TFP : controlling for the effect of corporate governance } \\
\hline & Overall sample & State-owned Firms & Hungarian Private Firms & Foreign Firms \\
\hline Real investment & $0.087 * * *$ & $0.014 *$ & $0.12 * * *$ & $0.051 * * *$ \\
\hline $\begin{array}{l}\text { Dummy set equal to one } \\
\text { when the majority of } \\
\text { equities is owned by the } \\
\text { State }\end{array}$ & $-0.288 * * *$ & & & \\
\hline $\begin{array}{l}\text { Dummy set equal to one } \\
\text { when the majority of } \\
\text { equities is owned by } \\
\text { private domestic firms }\end{array}$ & $-0.094 * * *$ & & & \\
\hline $\begin{array}{l}\text { Dummy set equal to one } \\
\text { when the majority of } \\
\text { equities is owned by } \\
\text { foreign firms }\end{array}$ & $-0.131 * * *$ & & & \\
\hline Constant & $0.535 * * *$ & $-0.084 *$ & $0.57 * * *$ & $0.245 * * *$ \\
\hline \multicolumn{5}{|c|}{ Gross TFP : not controlling for the effect of corporate governance } \\
\hline Real investment & $0.087 * * *$ & 0.006 & $0.122 * * *$ & $0.049 * * *$ \\
\hline $\begin{array}{l}\text { Dummy set equal to one } \\
\text { when the majority of } \\
\text { equities is owned by the } \\
\text { State }\end{array}$ & $-0.481 * * *$ & & & \\
\hline $\begin{array}{l}\text { Dummy set equal to one } \\
\text { when the majority of } \\
\text { equities is owned by } \\
\text { private domestic firms }\end{array}$ & -0.072 & & & \\
\hline $\begin{array}{l}\text { Dummy set equal to one } \\
\text { when the majority of } \\
\text { equities is owned by } \\
\text { foreign firms }\end{array}$ & -0.069 & & & \\
\hline Constant & $0.544 * * *$ & $-0.302 * * *$ & $0.607 * * *$ & $0.307 * * *$ \\
\hline
\end{tabular}

***: significant at 1 percent; *: significant at 10 percent.

\section{$\underline{\text { Section 2: investment behavior }}$}

According to the results of the previous analysis, both the distribution of investment and its impact on efficiency are differentiated by category of ownership. We are going to test now that the access to external credit is limited by capital market imperfections, and that firms are not indifferent between raising external funds and using internal resources. The following investment equation, which corresponds to the model in Prasnikar and Svejnar (2000), is estimated : 
$\log (\mathrm{I} / \mathrm{L})=\mathrm{a} 0+\mathrm{a} 1 \log (\mathrm{Tr} / \mathrm{L})+\mathrm{a} 2 \operatorname{cov}+\mathrm{a} 3 \log (\mathrm{yL} / \mathrm{L})+\mathrm{a} 4 \log (\mathrm{R} / \mathrm{L})+\mathrm{u}(\mathrm{i})+\mathrm{v}(\mathrm{t})(\mathrm{Eq} \cdot 3)$

Equivalently :

Invr $=\mathrm{a} 0+\mathrm{a} 1 \mathrm{tr}+\mathrm{a} 2 \operatorname{cov}+\mathrm{a} 3 \mathrm{ylr}+\mathrm{a} 4 \mathrm{rlr}+\mathrm{u}(\mathrm{i})+\mathrm{v}(\mathrm{t}) \quad$ (Eq.4)

Where I is the firm's gross real investment (total asset ( $\mathrm{t}$ ) minus total asset ( $\mathrm{t}-1)$ minus depreciation charge at $t$;

Tr denotes the firm's real trading profit;

Cov is the interest coverage ratio, computed as the ratio of the firm's interest expenses to the sum of the firm's interest expenses plus cash flow;

$\mathrm{yL}$ is the total labor cost per worker times the average number of employees;

$\mathrm{R}$ is the real sale revenue of the firm;

$\mathrm{L}$ is the average number of employees;

Table 5 : investment equation

\begin{tabular}{|c|c|c|c|c|c|c|c|c|}
\hline & \multicolumn{4}{|c|}{ Overall sample } & \multicolumn{4}{|c|}{ State-Owned Firms } \\
\hline $\mathrm{Tr}$ & $0.059 * * *$ & $0.033 * * *$ & $0.059 * * *$ & $0.0324 * * *$ & $0.112 * * *$ & $0.068 * * *$ & $0.101 * * *$ & $0.060 * * *$ \\
\hline Cov & & $-0.397 * * *$ & & $-0.409 * * *$ & & $-0.809 * * *$ & & $-0.771 * * *$ \\
\hline Rlr & $0.235 * * *$ & $0.2505 * * *$ & $0.282^{* * * *}$ & $0.299 * * *$ & $-0.207 * * *$ & $-0.152 * * *$ & $-0.323 * * *$ & $-0.262 * * *$ \\
\hline Ylr & & & $-0.151 * * *$ & $-0.159 * * *$ & & & $0.537 * * *$ & $0.487 * * *$ \\
\hline \multirow{2}{*}{$\begin{array}{l}\text { Number of } \\
\text { observations }\end{array}$} & 15694 & 15694 & 15691 & 15691 & 778 & 778 & 778 & 778 \\
\hline & \multicolumn{4}{|c|}{ Hungarian Private Firms } & \multicolumn{4}{|c|}{ Foreign Firms } \\
\hline $\mathrm{Tr}$ & $0.061 * * *$ & $0.0379 * * *$ & $0.060 * * *$ & $0.036 * * *$ & $0.043 * * *$ & 0.013 & $0.043 * * *$ & 0.013 \\
\hline $\mathrm{Cov}$ & & $-0.386 * * *$ & & $-0.396 * * *$ & & $-0.378 * * *$ & & $-0.377 * * *$ \\
\hline Rlr & $0.299 * * *$ & $0.316^{* * * *}$ & $0.356 * * *$ & $0.373 * * *$ & $0.159 * * *$ & $0.179 * * *$ & $0.153 * * *$ & $0.175 * * *$ \\
\hline Ylr & & & $-0.178 * * *$ & $-0.182 * * *$ & & & 0.017 & 0.012 \\
\hline $\begin{array}{l}\text { Number of } \\
\text { observations }\end{array}$ & 10483 & 10483 & 10482 & 10482 & 3099 & 3099 & 3099 & 3099 \\
\hline
\end{tabular}

The trading profit $(\mathrm{Tr})$ and interests pressure (cov) variables allow to test whether the investment behaviour of firms varies systematically with internal funds. In a "perfect" world, external funds, issuing equity or debt, and internal funds are perfect substitutes. But assume that there is a discrepancy between the information borrowers and lenders are provided with (incomplete asymmetric information), then a difference between the costs of internal and external funds appears and this difference is shown in the literature to depend upon the firm size and the creditworthiness of the borrowing firm. The primary measure of a firm's net worth is the Tobin's Q (as a proxy for expected future profitability), which is neither available nor reliable in most transition countries. Instead, we augment the Euler equation by 
including the two above mentioned variables, $t r$ and $\operatorname{cov}$. If a1 $>0$ (and a2 $<0$ ), investment is sensible to the availability of internal funds, proxied by cash flows and interests pressure on firm's liquidity, then the capital market imperfection hypothesis holds.

It is usually assumed that credit rationing (independent from future profitability) introduces a distorting bias against certain firms. In transition countries, one has to be aware that because of moral hazard and adverse selection, the bias might work in a specific direction: are loss makers more largely provided with cheap credit and more able to raise credit despite their losses? In other words, the elasticity of investment to cash flows can be considered as reflecting the process of budget constraint's hardening, and the sensibility of investment to the availability of internal funds is more the consequence of the moral hazard problem than that of asymmetric information.

This has an important practical consequence for the a priori grouping of rationed and not rationed firms. The degree of softness of the budget constraint is more relevant for discriminating firms, than more traditional variables (as listed in Hubbard (1998), like the size, number of employees, debt burden), which might fail in detecting and describing the market imperfection at work in a transition country. Budina and alii. (2000) for instance argue that for most studies of Western economies the intuition is that companies with a relatively large amount of debt are more likely to face liquidity constraints, whatever their profitability. In transition countries $\frac{14}{4}$ and particularly in Bulgaria, the opposite holds. Indebted firms are less likely to face credit rationing, but this does not imply that the market is "perfect". In certain transition countries, indebtedness is more a proxy for the degree of softness of the budget constraint than for the availability of internal funds. Here the ownership structure: domestic and private, foreign, and State-owned, was used for a priori grouping the firms in three sub-samples.

The inclusion of the labor cost allows to take into account the bargaining between workers and managers over the allocation of value added. If workers are able to appropriate part of the investable surplus, a3 should be negative.

Finally the sale revenue variable captures the investment effect of output demand. The accelerator and neoclassical models imply that a4 $>0$. By proxing credit constraints with two variables, $t r$ and cov, we take into account that the $\operatorname{tr}$ coefficient may capture some of the output demand effect on investment.

\footnotetext{
${ }^{14}$ Fan, Lee and Shaffer (1996), or Maurel, Brana, and Sgard (1998) provide evidence for adverse selection in Russia: indebted firms are less profitable than firms with no indebtedness.
} 
The coefficients in table 4 are remarkably stable across the different specifications and have the expected sign: negative for cov and $y L r$, positive for $r l r$ and $t r$. These results indicate that there is a trade-off between investment and wage increases and that any increase in output demand has a positive impact on investment. The behaviour of State-owned firms is not consistent with the profit maximisation hypothesis inherent in the neoclassical and accelerator model of investment: investment increases when sales decrease; there is no tradeoff between investment and wages, which increase together with investment, while sales and profit decrease over the same period. Both results provide evidence for persisting soft budget constraint. Finally while foreign firms do not face an arbitrage between real investment and wages, Hungarian private firms do.

More importantly the correlation between investment and internal funds is significant (investment increases when internal funds are available). By assuming that the magnitude of credit constraint is the sum of both cov and tr times their respective elasticity, it turns out that State-owned firms are more credit constrained than private Hungarian firms and foreign firms. A similar result is found from Czech Panel Data in Lizal and Svejnar (2001): foreign firms invest the most. Nevertheless Czech State-owned firms continue to be provided with a large volume of bad loans and to operate under a soft budget constraint, while in Hungary statistical evidence shows that State investment dropped significantly and credit rationing is quite substantial. Last but not least foreign firms have an easier access to external funds than the other two categories of Hungarian firms.

\section{Section 3: the crowding out hypothesis}

Following a methodology introduced by Ann E. Harrisson and Margaret S. McMillan (2001), we test the assumption that foreign borrowing, which in section 1 was found to be much higher, may exacerbate credit constraints for the individual firms in the sector. We interact our measure of credit constraint, cov, with the share of foreign borrowing in the sector (cov_Fbor). This term is meant to capture "credit rationing" by lenders. We expect the coefficient to be negative.

We add Cov_Fsal, which is cov times the share of foreign sales in the sector in order to take into account the fact that foreign sales could make domestic firms less profitable and therefore less able to borrow. Proceeding that way, we are able to test our crowding out assumption via financial markets. If domestic firms are crowed out of local markets due to 
market competition, then adding this additional term should reduce or eliminate the significance of crowding out in the financial sector.

The results are in the following table. With respect to the benchmark equation (without cov_Fbor and cov_Fsal in table 4), all coefficients, except that of cov, remain the same. The assumption of crowding out is validated. It has two components: crowding out via financial market and via product market competition. In other words, foreign firms borrow more for two reasons: they are more competitive, and have a better access to external funds (whatever domestic or international).

Table 5a : crowding out

\begin{tabular}{|l|c|c|}
\hline $\begin{array}{l}\text { Explained variables: real } \\
\text { investment }\end{array}$ & Coefficients & Z Statistics \\
\hline Tr & 0.031 & -1.018 \\
\hline Cov & -0.084 & -1.792 \\
\hline $\begin{array}{l}\text { Cov_Fbor: interest pressures } \\
\text { times foreign borrowing in } \\
\text { the sector }\end{array}$ & -0.218 & -2.838 \\
\hline $\begin{array}{l}\text { Cov_Fsal: interest pressures } \\
\text { times foreign sales in the } \\
\text { sector }\end{array}$ & -0.510 & \\
\hline Rlr & & 20.232 \\
\hline Ylr & 0.299 & -8.067 \\
\hline Constant & -0.161 & -50.262 \\
\hline R2 within & -5.460 & \\
\hline R2 between & 0.09 & \\
\hline R2 overall & 0.01 & \\
\hline Number of observations & 0.02 & \\
\hline Number of groups & 15378 & \\
\hline Wald Chi2(6) & 5253 & \\
\hline Prob > Chi2 & 962.56 & \\
\hline
\end{tabular}

We perform below in table $5 \mathrm{~b}$ the same analysis but by assuming that State-owned firms may exacerbate credit constraints for other firms in some sector: the assumption is clearly rejected. 
$\underline{\text { Table } 5 \mathrm{~b} \text { : crowding out }}$

\begin{tabular}{|l|c|c|}
\hline $\begin{array}{l}\text { Explained variables: real } \\
\text { investment }\end{array}$ & Coefficients & Z Statistics \\
\hline Tr & 0.031 & -8.77 \\
\hline Cov & -0.373 & -1.67 \\
\hline $\begin{array}{l}\text { Cov_Sbor: interest pressures } \\
\text { times State-owned firms } \\
\text { borrowing in the sector }\end{array}$ & -0.571 & -1.08 \\
\hline $\begin{array}{l}\text { Cov_Ssal: interest pressures } \\
\text { times State-owned firms sales } \\
\text { in the sector }\end{array}$ & -0.271 & \\
\hline R1r & & 19.97 \\
\hline Ylr & 0.295 & -7.68 \\
\hline Constant & -0.154 & -50.36 \\
\hline R2 within & -5.479 & \\
\hline R2 between & 0.0935 & \\
\hline R2 overall & 0.0122 & \\
\hline Number of observations & 0.0225 & \\
\hline Number of groups & 15678 & \\
\hline Wald Chi2(6) & 5253 & \\
\hline Prob $>$ Chi2 & 946.29 & \\
\hline
\end{tabular}

\section{Conclusion}

This paper highlights two measures of efficiency, computed as TFP form a Cobb-Douglas technology, gross and net of property structure. Gross efficiency is the fixed effect in the production function specification, which does not include property variables, while net efficiency is net of the effect of corporate governance on the ratio of production to factors contribution. Contrary to Laslo Halpern and Gabor Korosi (2000), who found that in the early years of transition the link between efficiency and investment is rather loose, and that foreign firms are more efficient, while state-owned are not significantly different from the average, our results emphasise that both foreign and private Hungarian firms are more efficient and invest more than State-owned firms.

Our estimate of the elasticity of efficiency with respect to investment suggests that private firms benefit much more from an incremental investment than other firms, particularly foreign firms. This has to be linked with the previous result of an higher than average foreign firms investment level, and may reflect the higher marginal productivity of private domestic firms investment.

Credit rationing applies for all categories of firms: as Lizal and Svejnar (2001), we do consider than this results only partially corroborates the Calvo and Coricelli's credit crunch hypothesis. First, all enterprises, including foreign ones, face a restricted access to external funds, and we do not assume that foreign firms may be concerned by the credit crunch argument. Second, State-owned firms do not have a profit maximization behaviour (the 
positive correlation between wages and investment is worse than the arbitrage assumption in Prasnikar J. and Svejnar J. (2000)), which is not compatible with the idea that liquidity shortage may induce a recession spiral. Nevertheless domestic private firms would benefit from an easier access to credit.

We further investigate the possibility that Hungarian firms are crowed out by foreign investment via financial markets, by controlling for both higher competitiveness and implied larger market share of foreign firms. Our data validate the crowding out assumption via financial market. Using the same methodology, we reject the possibility that State-owned firms bad loans jeopardise investment, by crowding out more profitable and credit rationed firms.

\section{$\underline{\text { References }}$}

Brana Sophie, Mathilde Maurel, and Jérôme Sgard (1999): "Enterprise Adjustment and the Role of Bank Credit in Russia: Evidence from a 420 Firm's Qualitative Survey", Comparative economic Studies, Vol. XLI, nº4.

Budina Nina, Garretsen Harry, de Jong Eelke (2000), "Liquidity constraints and investment in transition economies, the case of Bulgaria", Economics of Transition, Vol. 8 (2), 453-475.

Calvo Guillermo A., Fabrizio Coricelli (1994), "Capital Market Imperfections and Output Response in Previously Centrally Planned Economies”, in Caprio G., Folerts-Landau D. and Lane T. (Eds.). Building Sound Finance in Emerging Market Economies, Washington, D.C: IMF.

Cull Robert, Lixin Colin Xu (2000), "Bureaucrats, State Banks, and the Efficiency of Credit Allocation: The Experience of Chinese State-Owned Enterprises”, Journal of Comparative Economics, Vol. 28, $\mathrm{n}^{\circ} 1$, pp. 1-31.

Estrin Saul, Jozef Konings, Zbigniew Zolkiewski, Manuela Angeluci (2001), "The effect of Ownerships and Competitive Pressure on Firm Performance in Transition Countries. Micro Evidence from Bulgaria, Romania and Poland", LICOS Discussion Paper 104.

Fazzari Steven M., Hubbard Glenn R. and Petersen Bruce C., 1998, «Financing constraints and corporate investment», Brooking Papers on Economic Activity, pp. 141-206.

Grosfeld Irena and Roland Gérard, 1997, «Defensive and Strategic Restructuring in Central European Enterprises », Journal of Transforming Economies and Societies, vol.3 n4, pp. 2146.

Grosfeld Irena and Thierry Tressel, 2001, «Competition and Corporate Governance: Substitutes or Complements? Evidence from the Warsaw Stock Exchange», WDI Working Paper $n^{\circ} 369$. 
Halpern Laslo, Korosi Gabor, 2000, «Efficiency and Market share in Hungarian Corporate Sector», paper presented at the CEPR/WDI Annual International Conference on Transition Economics.

Hubbard Glenn R., 1998, «Capital Market imperfections and Investment», Journal of Economic Literature, Vol. 36, ${ }^{\circ}$ 1, pp. 193-225.

Kaplan Stephen, Zingales Luigi, 1997, «Do investment-Cash Flows sensitivities provide useful measures of financing constraints», The Quarterly Journal of Economics, pp. 167-215. Lizal Lubomir, Jan Svenjar (2001), "Investment, Credit Rationing and the Soft Budget Constraint: Evidence from Czech Panel Data", WDI Working Paper $n^{\circ} 363$, forthcoming in The Review of Economics and Statistics.

Prasnikar Janez, Svejnar Jan, 2000, «Investment, Wages and Ownership during the Transition to a Market Economy: Evidence from Slovenian Firms», paper presented at the CEPR/WDI Annual International Conference on Transition Economics. 
ANNEX: Table 1: summary statistics

\begin{tabular}{|c|c|c|c|}
\hline \multicolumn{4}{|c|}{ Total Assets } \\
\hline & $\begin{array}{l}\text { Total } \\
\text { sample }\end{array}$ & 1993 & 1998 \\
\hline $\begin{array}{l}\text { State-owned } \\
\text { enterprise }\end{array}$ & 1711060 & 2032121 & 1529834 \\
\hline Std Dev & $1.18 e+07$ & $1.47 e+07$ & $1.00 e+07$ \\
\hline Numb of obs & 2693 & 885 & 216 \\
\hline $\begin{array}{l}\text { Private } \\
\text { Domestic } \\
\text { enterprises }\end{array}$ & 167746 & 136595 & 197000 \\
\hline Std Dev & 1341748 & 599839 & 1427095 \\
\hline Numb of obs & 19898 & 3122 & 3259 \\
\hline $\begin{array}{l}\text { Foreign } \\
\text { enterprises }\end{array}$ & 936283 & 695960 & 1292782 \\
\hline Std Dev & 3453589 & 1959535 & 5375025 \\
\hline Numb of obs & 5906 & 800 & 1066 \\
\hline
\end{tabular}

\begin{tabular}{|c|c|c|c|}
\hline \multicolumn{4}{|c|}{ Trading profit by employee } \\
\hline & $\begin{array}{l}\text { Total } \\
\text { sample }\end{array}$ & 1993 & 1998 \\
\hline $\begin{array}{l}\text { State-owned } \\
\text { enterprise }\end{array}$ & 147 & 136 & 94 \\
\hline Std Dev & 699 & 618 & 182 \\
\hline Numb of obs & 1375 & 390 & 142 \\
\hline $\begin{array}{l}\text { Private } \\
\text { Domestic } \\
\text { enterprises }\end{array}$ & 281 & 253 & 243 \\
\hline Std Dev & 3657 & 808 & 922 \\
\hline Numb of obs & 13996 & 1971 & 2504 \\
\hline $\begin{array}{l}\text { Foreign } \\
\text { enterprises }\end{array}$ & 594 & 480 & 666 \\
\hline Std Dev & 1452 & 798 & 1636 \\
\hline Numb of obs & 3878 & 432 & 759 \\
\hline
\end{tabular}

\begin{tabular}{|c|c|c|c|}
\hline \multicolumn{4}{|c|}{$\begin{array}{c}\text { Positive investment as a } \\
\text { percent of total positive } \\
\text { investment }\end{array}$} \\
\hline & $\begin{array}{l}\text { Total } \\
\text { sample }\end{array}$ & 1994 & 1998 \\
\hline $\begin{array}{l}\text { State-owned } \\
\text { enterprise }\end{array}$ & $6 \%$ & $7 \%$ & $18 \%$ \\
\hline Std $D e v$ & $5.04 \%$ & & \\
\hline Numb of obs & 1815 & 613 & 216 \\
\hline $\begin{array}{l}\text { Private } \\
\text { Domestic } \\
\text { enterprises }\end{array}$ & $24 \%$ & $31 \%$ & $20 \%$ \\
\hline Std Dev & $3.86 \%$ & & \\
\hline Numb of obs & 16814 & 3359 & 3259 \\
\hline $\begin{array}{l}\text { Foreign } \\
\text { enterprises }\end{array}$ & $66 \%$ & $55 \%$ & $60 \%$ \\
\hline Std $D e v$ & $6.89 \%$ & & \\
\hline Numb of obs & 5111 & 882 & 1066 \\
\hline
\end{tabular}

\begin{tabular}{|c|c|c|c|}
\hline \multicolumn{4}{|c|}{ Number of employees } \\
\hline & $\begin{array}{l}\text { Total } \\
\text { sample }\end{array}$ & 1993 & 1998 \\
\hline $\begin{array}{l}\text { State-owned } \\
\text { enterprise }\end{array}$ & 351 & 382 & 250 \\
\hline Std Dev & 1071 & 898 & 584 \\
\hline Numb of obs & 2634 & 869 & 210 \\
\hline $\begin{array}{l}\text { Private } \\
\text { Domestic } \\
\text { enterprises }\end{array}$ & 90 & 83 & 96 \\
\hline Std Dev & 183 & 158 & 211 \\
\hline Numb of obs & 19502 & 3071 & 3231 \\
\hline $\begin{array}{l}\text { Foreign } \\
\text { enterprises }\end{array}$ & 191 & 166 & 230 \\
\hline Std Dev & 453 & 447 & 497 \\
\hline Numb of obs & 5776 & 761 & 1059 \\
\hline
\end{tabular}

\begin{tabular}{|c|c|c|c|c|c|c|c|}
\hline \multicolumn{4}{|c|}{ Wages (payment to one employee) } & \multicolumn{4}{|c|}{$\begin{array}{l}\text { TFP excluding the effect of } \\
\text { corporate governance }\end{array}$} \\
\hline & $\begin{array}{l}\text { Total } \\
\text { sample }\end{array}$ & 1993 & 1998 & & $\begin{array}{l}\text { Total } \\
\text { sample }\end{array}$ & 1993 & 1998 \\
\hline $\begin{array}{l}\text { State-owned } \\
\text { enterprise }\end{array}$ & 466 & 436 & 486 & $\begin{array}{l}\text { State-owned } \\
\text { enterprise }\end{array}$ & -0.184 & $\overline{0} .182$ & $\begin{array}{l}- \\
0.171\end{array}$ \\
\hline Std Dev & 382 & 482 & 372 & Std Dev & 0.632 & 0.608 & 0.674 \\
\hline Numb of obs & 2633 & 869 & 210 & Numb of obs & 2613 & 864 & 209 \\
\hline $\begin{array}{l}\text { Private } \\
\text { Domestic } \\
\text { enterprises }\end{array}$ & 404 & 445 & 386 & $\begin{array}{l}\text { Private } \\
\text { Domestic } \\
\text { enterprises }\end{array}$ & 0.091 & 0.057 & 0.108 \\
\hline Std Dev & 518 & 921 & 314 & Std Dev & 0.608 & 0.650 & 0.576 \\
\hline Numb of obs & 19483 & 3069 & 3230 & Numb of obs & 19377 & 3039 & 3218 \\
\hline $\begin{array}{l}\text { Foreign } \\
\text { enterprises }\end{array}$ & 626 & 622 & 649 & $\begin{array}{l}\text { Foreign } \\
\text { enterprises }\end{array}$ & 0.093 & 0.064 & $\overline{0}-\overline{0} 028$ \\
\hline Std Dev & 620 & 534 & 492 & Std Dev & 0.674 & 0.675 & 0.700 \\
\hline Numb of obs & 5763 & 758 & 1059 & Numb of obs & 5716 & 749 & 1056 \\
\hline
\end{tabular}


Table 1 (followed)

\begin{tabular}{|c|c|c|c|c|c|c|c|c|c|c|c|}
\hline \multicolumn{4}{|c|}{ Net Sales Revenues } & \multicolumn{4}{|c|}{$\begin{array}{c}\text { Interests paid/(interests paid }+ \\
\text { trading profit) } \\
\text { (cov variable) }\end{array}$} & \multicolumn{4}{|c|}{$\begin{array}{l}\text { TFP including the effect of } \\
\text { corporate governance }\end{array}$} \\
\hline & $\begin{array}{l}\text { Total } \\
\text { sample }\end{array}$ & 1993 & 1998 & & $\begin{array}{l}\text { Total } \\
\text { sample }\end{array}$ & 1993 & 1998 & & $\begin{array}{l}\text { Total } \\
\text { sample }\end{array}$ & 1993 & 1998 \\
\hline $\begin{array}{l}\text { State-owned } \\
\text { enterprise }\end{array}$ & 1031624 & 1176310 & 892362 & $\begin{array}{l}\text { State-owned } \\
\text { enterprise }\end{array}$ & $12 \%$ & $7 \%$ & $46 \%$ & $\begin{array}{l}\text { State-owned } \\
\text { enterprise }\end{array}$ & -0.36 & $-\overline{0.33}$ & $\overline{0}-39$ \\
\hline Std Dev & 6378156 & 8513440 & 6767068 & Std Dev & 5.38 & 2.84 & 6.55 & Std Dev & 0.65 & 0.64 & 0.69 \\
\hline Numb of obs & 2690 & 886 & 215 & Numb of obs & 2702 & 886 & 216 & Numb of obs & 2613 & 864 & 209 \\
\hline $\begin{array}{l}\text { Private } \\
\text { Domestic } \\
\text { enterprises }\end{array}$ & 217428 & 173591 & 261741 & $\begin{array}{l}\text { Private } \\
\text { Domestic } \\
\text { enterprises }\end{array}$ & $9 \%$ & $-12 \%$ & $20 \%$ & $\begin{array}{l}\text { Private } \\
\text { Domestic } \\
\text { enterprises }\end{array}$ & 0.12 & 0.08 & 0.13 \\
\hline Std Dev & 885986 & 699376 & 1035570 & Std Dev & 17.07 & 19.19 & 4.26 & Std Dev & 0.62 & 0.66 & 0.58 \\
\hline Numb of obs & 19895 & 3146 & 3246 & Numb of obs & 19947 & 3144 & 3257 & Numb of obs & 19377 & 3039 & 3218 \\
\hline $\begin{array}{l}\text { Foreign } \\
\text { enterprises }\end{array}$ & 1083468 & 639915 & 1697740 & $\begin{array}{l}\text { Foreign } \\
\text { enterprises }\end{array}$ & $10 \%$ & $13 \%$ & $5 \%$ & $\begin{array}{l}\text { Foreign } \\
\text { enterprises }\end{array}$ & 0.08 & 0.13 & 0.04 \\
\hline Std Dev & 5466828 & 1805798 & 9725335 & Std $D e v$ & 3.78 & 1.85 & 2.59 & Std Dev & 0.68 & 0.68 & 0.71 \\
\hline Numb of obs & 5860 & 792 & 1063 & Numb of obs & 5906 & 799 & 1065 & Numb of obs & 5716 & 749 & 1056 \\
\hline
\end{tabular}

\begin{tabular}{|c|c|c|c|}
\hline & $\begin{array}{l}\text { Total } \\
\text { sample }\end{array}$ & 1993 & 1998 \\
\hline $\begin{array}{l}\text { State-owned } \\
\text { enterprise }\end{array}$ & 2253 & 2018 & 3262 \\
\hline Std Dev & 9588 & 8152 & 16207 \\
\hline Numb of obs & 2621 & 867 & 209 \\
\hline $\begin{array}{l}\text { Private } \\
\text { Domestic } \\
\text { enterprises }\end{array}$ & 2711 & 2593 & 2636 \\
\hline Std $D e v$ & 8171 & 5845 & 3962 \\
\hline Numb of obs & 19431 & 3065 & 3218 \\
\hline $\begin{array}{l}\text { Foreign } \\
\text { enterprises }\end{array}$ & 5211 & 4517 & 5732 \\
\hline Std $D e v$ & 11715 & 8581 & 12184 \\
\hline Numb of obs & 5723 & 751 & 1056 \\
\hline
\end{tabular}

\begin{tabular}{|c|c|c|c|}
\hline \multirow{2}{*}{$\begin{array}{l}\text { Investment }=\text { in } \\
\text { assets, net of }\end{array}$} & \multicolumn{3}{|c|}{$\begin{array}{l}\text { (decrease) in } \\
\text { iation charge }\end{array}$} \\
\hline & $\begin{array}{l}\text { Total } \\
\text { sample }\end{array}$ & 1994 & 1998 \\
\hline $\begin{array}{l}\text { State-owned } \\
\text { enterprise }\end{array}$ & $-\overline{2} 26379$ & $-\overline{263186}$ & 97444 \\
\hline Std Dev & & & \\
\hline Numb of obs & 1442 & 495 & 208 \\
\hline $\begin{array}{l}\text { Private } \\
\text { Domestic } \\
\text { enterprises }\end{array}$ & -9491 & -5414 & -4143 \\
\hline Std $D e v$ & & & \\
\hline Numb of obs & 14612 & 2925 & 3175 \\
\hline $\begin{array}{l}\text { Foreign } \\
\text { enterprises }\end{array}$ & 71132 & 65006 & 120596 \\
\hline Std Dev & & & \\
\hline Numb of obs & 4418 & 768 & 1034 \\
\hline
\end{tabular}




\section{DAVIDSON INSTITUTE WORKING PAPER SERIES - Most Recent Papers}

The entire Working Paper Series may be downloaded free of charge at: www.wdi.bus.umich.edu

CURRENT AS OF 11/15/01

\begin{tabular}{|c|c|c|}
\hline Publication & Authors & Date \\
\hline $\begin{array}{l}\text { No. 403: Investment, Efficiency, and Credit Rationing: Evidence from } \\
\text { Hungarian Panel Data }\end{array}$ & Mathilde Maurel & Nov. 2001 \\
\hline $\begin{array}{l}\text { No. 402: Subduing High Inflation in Romania. How to Better Monetary } \\
\text { and Exchange Rate Mechanisms? }\end{array}$ & $\begin{array}{l}\text { Daniel Daianu and Radu } \\
\text { Vranceanu }\end{array}$ & Aug. 2001 \\
\hline $\begin{array}{l}\text { No. 401: The Gender Wage Gap in Bulgaria: A Semiparametric } \\
\text { Estimation of Discrimination }\end{array}$ & Dean Jolliffe & July 2001 \\
\hline $\begin{array}{l}\text { No. 400: Do External Auditors Perform a Corporate Governance Role in } \\
\text { Emerging Markets? Evidence from East Asia }\end{array}$ & Joseph P. H. Fan and T.J. Wong & Oct. 2001 \\
\hline $\begin{array}{l}\text { No. 399: Financial Conditions and Investment during the Transition: } \\
\text { Evidence from Czech Firms }\end{array}$ & Lubomír Lízal and Jan Svejnar & Oct. 2001 \\
\hline $\begin{array}{l}\text { No. 398: Accessible Pareto-Improvements: Using Market Information to } \\
\text { Reform Inefficiencies }\end{array}$ & Michael Mandler & May 2001 \\
\hline No. 397: The Making of an Integrated National Grain Market in China & Wubiao Zhou & Oct. 2001 \\
\hline No. 396: Corruption and Resource Allocation: Evidence from China & Wei Li & June 2001 \\
\hline $\begin{array}{l}\text { No. 395: Government Shareholding and the Value of China's Modern } \\
\text { Firms }\end{array}$ & Lihui Tian & Apr. 2001 \\
\hline No. 394: Labor Hoarding in Russia: Where Does it Come from? & $\begin{array}{l}\text { Rouslan Koumakhov and Boris } \\
\text { Najman }\end{array}$ & June 2000 \\
\hline $\begin{array}{l}\text { No. 393: Ownership Structure, Corporate Governance, And Firm Value: } \\
\text { Evidence from the East Asian Financial Crisis }\end{array}$ & Michael Lemmon and Karl Lins & Apr. 2001 \\
\hline No. 392: Marshall and Labour Demand in Russia: Going Back to Basics & $\begin{array}{l}\text { Jozef Konings and Hartmut } \\
\text { Lehmann }\end{array}$ & Aug. 2001 \\
\hline No. 391: Economic Transition and Elections in Poland & $\begin{array}{l}\text { John E. Jackson, Jacek Klich, and } \\
\text { Krystyna Poznańska }\end{array}$ & June 2001 \\
\hline $\begin{array}{l}\text { No. 390: Effects of Bank Insolvency and Strategic Uncertainty on } \\
\text { Corporate Restructuring in Transition Economies }\end{array}$ & Christa Hainz & Aug. 2001 \\
\hline No. 389: Mark-Up Pricing In Bulgarian Manufacturing & $\begin{array}{l}\text { Rumen Dobrinsky, Boyko } \\
\text { Nikolov, and Nikolay Markov }\end{array}$ & June 2001 \\
\hline $\begin{array}{l}\text { No. 388: Globalization and Firms' Financing Choices: } \\
\text { Evidence from Emerging Economies }\end{array}$ & $\begin{array}{l}\text { Sergio Schmukler and Esteban } \\
\text { Vesperoni }\end{array}$ & May 2001 \\
\hline $\begin{array}{l}\text { No. 387: The Distributional Impacts of Indonesia's Financial Crisis on } \\
\text { Household Welfare: A "Rapid Response" Methodology }\end{array}$ & $\begin{array}{l}\text { Jed Friedman and James } \\
\text { Levinsohn }\end{array}$ & Sept. 2001 \\
\hline $\begin{array}{l}\text { No. 386: Corporate Financial Policies and Performance Prior to Currency } \\
\text { Crises }\end{array}$ & $\begin{array}{l}\text { Arturo Bris, Yrjö Koskinen, and } \\
\text { Vicente Pons }\end{array}$ & June 2001 \\
\hline No. 385: Ownership and Productive Efficiency: Evidence from Estonia & Derek C. Jones and Niels Mygind & Aug. 2001 \\
\hline $\begin{array}{l}\text { No. 384: Forthcoming in: Journal of Economic Perspectives, } \\
\text { "Institutional Determinants of Labor Reallocation in Transition" Vol. } \\
\text { 16, No. 2, Feb. } 2002 \text {. }\end{array}$ & Tito Boeri and Katherine Terrell & June 2001 \\
\hline $\begin{array}{l}\text { No. 383: Deindustrialisation and Structural Change During the Post- } \\
\text { Communist Transition }\end{array}$ & $\begin{array}{l}\text { Tomasz Mickiewicz and Anna } \\
\text { Zalewska }\end{array}$ & June 2001 \\
\hline No. 382: Markets and Growth & Štěpán Jurajda and Janet Mitchell & July 2001 \\
\hline $\begin{array}{l}\text { No. 381: Labor Market Discrimination During Post-Communist } \\
\text { Transition: A Monopsony Approach to the Status of Latvia's Russian } \\
\text { Minority }\end{array}$ & Robert S. Chase & Sept. 2000 \\
\hline No. 380: Dollarization of Liabilities in Non-tradable Goods Sector & Frédéric Chabellard & June 2001 \\
\hline $\begin{array}{l}\text { No. 379: Lessons from the Russian Meltdown: The Economics of Soft } \\
\text { Legal Constraints }\end{array}$ & Enrico Perotti & Mar. 2001 \\
\hline No. 378: Effective Tax Rates in Transition & Vlad Ivanenko & May 2001 \\
\hline
\end{tabular}

